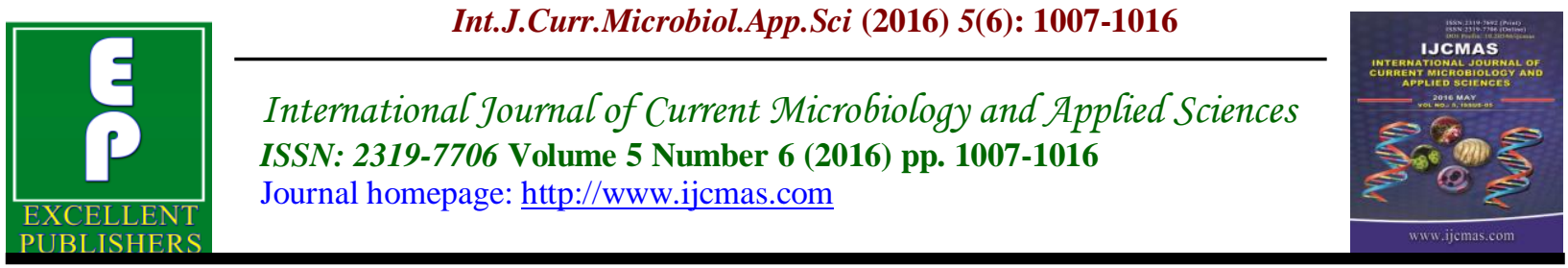

Original Research Article

http://dx.doi.org/10.20546/ijcmas.2016.506.107

\title{
Plant Growth Promoting Microbes, their Compatibility Analysis and Utility in Biointensive Management of Bacterial Wilt of Tomato
}

\author{
Bharat C. Nath, L.C. Bora, L. Kataki, K. Talukdar*, P. Sharma, J. Dutta and P. Khan \\ Department of Plant Pathology, Assam Agricultural University, Jorhat-785013, Assam, India \\ *Corresponding author
}

\section{A B S T R A C T}

Keywords

Biointensive management, bacterial wilt, tomato, plant growth promoting microbes, Ralstonia solanacearum

Article Info

Accepted:

20 May 2016

Available Online:

10 June 2016
A biointensive strategy was developed for management of bacterial wilt of tomato (Solanum esculentum Mill) caused by Ralstonia solanacearum using four compatible plant growth promoting microorganisms (PGPM),viz., Trichoderma parareesei, Pseudomonas fluorescens, Bacillus subtilis and Azotobacter chroococcum. Compatibility analysis among the PGPM showed positive interaction among themin vitro. The antagonistic potential of these PGPM was tested in vitro singly or in consortia and per cent inhibitions of target pathogen $R$. solanacearum were recorded and analyzed. The highest inhibition $(91.10 \%)$ of $R$. solanacearum was recorded against consortia of $T$. parareesei+ P.fluorescens + B.subtilis + A. chroococcum followed by T.parareesei+ P.fluorescens + B.subtilis $(81.10 \%)$ and P.fluorescens + B.subtilis + A.chroococcum (68.14\%). Talc based bioformulations were prepared using the best three PGPM and their consortia for management of bacterial wilt by applying these as seed treatment, root treatment and soil application under pot conditionduring 2013-2015 crop seasons. Significantly highest reduction of bacterial wilt incidence $(95.09 \%)$ and highest yield (1.692 kg/plant) of tomato was recorded in treatment comprising of $T$. parareesei+ P.fluorescens + B.subtilis + A.chroococcum. Correlation studies revealed negative correlation (-0.993) between bacterial wilt incidence and yield of tomato.

\section{Introduction}

Assam ranks $11^{\text {th }}$ in all India level of tomato production with 402.4 thousand MT in an area of 17.2 thousand ha and productivity of 23.2 MT/ha (Annon, 2013). Bacterial wilt disease is a serious limiting factor of tomato production in the state which is wide spread throughout all vegetable growing areas. The disease assumes serious proportion particularly in the years when environmental conditions favours the outbreak of the disease.
Different management practices like, use of chemicals, antibiotics, soil amendments, soil solarization etc., has been suggested by many workers to control the disease. However, management of the disease by a single control measure seems to be a difficult proposition due its wide host range and its long survival ability in soil. Therefore, there has been a growing concern to find alternative methods by exploiting potential of bioactive antagonists (Weller 
and Cook, 1983). Earlier, various biological agents have been employed for management of different crop diseases. Das and Bora (2000) used P. fluorescens, B. subtilis, T. harzianum, T. viride, T. koningii, Aspergillus terreus and $G$. virens for management of bacterial wilt in tomato. Similarly, Kumar and Sood (2001) found significant reduction in bacterial wilt incidence in tomato by application of $P$. fluorescens. Similarly, Azotobacter, which have ability to fix atmospheric nitrogen promotes root hair formation in seedling roots, increases plant weight during early crop growth stage (Rai and Gaur, 1988), produces phytohormones, antibiotics and enhances mineral uptake (Neumann and Romheld, 2001).Srivastava et al. (2010) studied the use of consortium of arbuscular mycorrhizal fungus, $T$. harzianum and fluorescent Pseudomonas formulation for management of tomato wilt.

In the present study attempts were made to explore some fungal and bacterial biocontrol agents along with few phosphate solubilising and nitrogen fixing microbes in developing a consortium package for developing a biointensive management strategy against bacterial wilt of tomato along with yield enhancement.

\section{Materials and Methods}

\section{Evaluation of Compatibility among Different Bioactive Microorganisms and development of Microbial Consortia}

The interaction study amongst different bioactive microorganisms, viz., $T$. parareesei, P. fluorescens, B. subtilisand A.chroococcum was tested for their compatibility using PDA and NA as basal mediafollowing dual culture techniques (Aspiras and Cruz, 1985) with few modifications. The test plates were incubated at $28 \pm 1^{\circ} \mathrm{C}$ for 48 to $96 \mathrm{hrs}$.
Altogether fifteen treatment combinations were tested and compared with growth of $T$. viride alone (Control-1), growth of $P$. fluorescens alone(Control-2), growth of $B$. subtilis alone (Control-3), and growth of A.chroococcum alone (Control-4).The microorganisms showing positive compatibility among themselves was recorded, tabulated and selected for further study.

The inhibitory effects of PGPMT. parareesei, P. fluorescens, B. subtilis, A.chroococcum and their consortia were tested in vitro against $R$. solanacearum adopting dual culture assay plate technique in pathogen favourable media (Triphenyl tetrazolium chloride). A total of sixteen treatment combinations were compared. Assay plates of $R$. solanacearum were prepared by seeding the $24 \mathrm{hr}$ growth of the bacterium in TTC. Following this, $0.5 \mathrm{~cm}$ bit of fungal antagonist $T$. parareesei grown in PDA was scooped out and transferred to the center of TTC plates seeded with $R$. solanacearum. Following the same procedure, $0.5 \mathrm{~cm}$ diameter lawn of $P$. fluorescens, B. subtilis and A.chroococcum grown in NA was scooped out separately and transferred to the center of TTC plates. Test plates seeded only with $R$. solanacearum served as control. The plates were then incubated at $28 \pm 1^{\circ} \mathrm{C}$. The inhibitions produced by the bioactive microorganisms and their consortia were measured after 48-96 hrs of dual inoculation. Based on the percent of inhibitions shown by the bioactive microorganisms or their combinations in vitro, three best treatments were selected for their further study.

\section{Preparation of Bioformulations of Bioactive Microorganisms}

Polypropylene (PP) bags were filled with $1 \mathrm{~kg}$ finely sieved talcum powder (substrate), 
sterilized at $121^{\circ} \mathrm{C}$ for 15 minutes. Pure culture of the fungal antagonist $T$. parareesei was grown in Potato Dextrose (PD) broth and incubated at $28 \pm 1{ }^{\circ} \mathrm{C}$ for $72 \mathrm{hr}$ to obtain a concentration of $1 \times 10^{7}$ colony forming units (cfu/ml). Pure cultures of $P$. fluorescens, $B$. subtilis, A.chroococcum were grown in $\mathrm{KB}$ and $\mathrm{NA}$ slants and incubated at $28 \pm 1^{\circ} \mathrm{C}$ for $24 \mathrm{hr}$. To these slants, sterile water added and bacterial suspensions $(15 \mathrm{ml})$ of the three bacteria was aseptically taken separately and added to 1 lit of Nutrient broth contained in conical flasks. This flask after thorough stirring was incubated at $28 \pm 1^{\circ} \mathrm{C}$ for $72 \mathrm{hr}$ to obtain a population of $1 \times 10^{7} \mathrm{cfu} / \mathrm{ml}$. Then $10 \mathrm{ml}$ of the each fungal and bacterial cells was inoculated in the above sterilized PP bags containing $1 \mathrm{~kg}$ talcum powder. To facilitate greater adherence property of the substrate, $10 \mathrm{ml}$ of sticker, carboxy-methyl cellulose (CMC @ 1\%) was added aseptically. Similarly, $10 \mathrm{ml}$ of an osmoticant (mannitol @ 3\%) was added to impart the substrate a higher moisture retaining property. The PP bags after thorough mixing were incubated at $28 \pm 1^{\circ} \mathrm{C}$ for 7 days to get desired concentration of each bioformulation.

\section{Efficacy of Bioformulation Based on Bioactive Microorganisms and their Consortia in Management of Bacterial Wilt of Tomato}

Three best bioactive microorganisms showing inhibitory property against $R$. Solanacearum in vitro were selected for further evaluation of their ability to suppress bacterial wilt of tomato using cultivar Pusa Ruby, during crop seasons 2013-5. BioforPf-2, organic biopesticide produced in Assam Agricultural University, Jorhat, was also used as a control treatment. The treatment combinations arrange in CRD with 5 replications were: Compatible bioactive microbe $-1(\mathrm{CBM})$ as seed + root
+ soil treatment; Compatible bioactive microbe - $2(\mathrm{CBM})$ as seed + root + soil treatment; Compatible bioactive microbe -3 $(\mathrm{CBM})$ as seed + root + soil treatment; Biofor-Pf-2 as seed + root + soil treatment; Control.

The substrate based bioformulation of $T$. parareesei; P. fluorescens, B. subtilis and A.chroococcum were applied as seed treatment, root dip treatment and soil application methods. For seed treatment, paste slurry of each substrate based formulation was prepared and to these paste slurry, tomato seeds were dipped @ 1000 seed/100 ml of paste solution for $1 \mathrm{hr}$.The treated seeds were then sown in the tomato nursery. For root treatment, each of the substrate based formulations was mixed withwater@ $20 \mathrm{gm}$ in $1000 \mathrm{ml}$ to prepare 2 per centbio-formulation solution. At the time of transplanting uprooted plants were root dipped (@1000 seedlings/1000ml) in the solution for $1 \mathrm{hr}$. Treated seedlings were dried under shade for $1 \mathrm{hr}$ before transplanting in to the earthen pots. For soil application, each of bioformulation was mixed with soil @100 g/plant after 15 days of sowing, at the base of the plants. The number of wilted plants was recorded throughout the experiment. The data were tabulated and disease incidence (DI \%) was calculated. The yield of each treatment $(\mathrm{kg})$ was recorded at harvest.

\section{Results and Discussion}

\section{Interactive Action of bioactive microorganisms}

Interactive action among $T$. parareesei, $P$. fluorescens, B. subtilis and A. chroococcum were tested in vitro adopting dual culture assay plate technique in PDA and NA as basal media. The data showed compatibility among all the treatment combinations of the 
four bioactive microorganisms in vitro (Table 1).

Four bioactive microorganisms produced varying inhibitions (\%)in vitro against $R$. solanacearum (Table 2). The inhibition (\%) produced by the consortia of four bioactive microorganisms T.parareesei+ $P$. fluorescens + B. subtilis + A.chroococcum was significantly highest $(91.10 \%)$ followed by $T$.parareesei+ $P$. fluorescens $+B$. subtilis (78.33\%). Among individual bioactive microorganisms highest inhibition was shown by T.parareesei $(53.94 \%)$ followed by P.fluorescens (50.00\%). Among individual bioagents, the lowest inhibition per cent was showed by A.chroococcum $(27.77 \%)$.

\section{Efficacy of Different Bioactive} Microorganisms and their Consortia based Formulations in Management of bacterial wilt of tomato

Bioformulations of different combinations of T. parareesei, P. fluorescens, B. subtilis and $A$. chroococcum were applied as seed, root and soil treatment for management of bacterial wilt of tomato. The effect of these bioformulations of was also compared with efficacy of Biofor-Pf 2 (a popular bioformulation of Assam) applied as seed, root and soil treatment. The disease incidance of tomatodecreased significantly accompanied by significant increase of yield $(\mathrm{kg} /$ plant $)$ in plants treated with consortia of different bioactive microorganisms (Table 4). Lowest disease incidence $(4.04 \%)$ was exhibited by the consotia of $T$. parareese + $P$. fluorescens + B. subtilis $+A$. chroococcum followed by T.viride $+P$. fluorescens + B. subtilis (10.27\%)applied asseed treatment, root treatment and soil treatment. Plants untreated with bioformulation showed highest disease incidence $(81.75 \%)$. The yield data of tomato (Table 3) showed that significantly highest yield (kg/plant) was recovered from plants treated with bioformulation consortia of $T$. parareesei $+P$. fluorescens $+B$. subtilis+ A. chroococcum (1.692 kg/plant) followed by $T$. parareese $+P$. fluorescens + B. subtilis $(1.516 \mathrm{~kg} /$ plant$)$ applied asseed treatment, root treatment and soil treatment. Plants untreated with bioformulation showed lowest yield $(0.369 \mathrm{~kg} /$ plant $)$.

\section{Correlation Studies}

A correlation was drawn between the disease incidance and the yield of different treatments. From the correlation studies, it was evident that there was a negetive correlation(-0.993) between disease incidance $(\%)$ and yield (kg/plant) of the different treatments. From the data presented in the Table 3, simple linear regression line (Fig. 1) was drawn taking disease incidance as independent value and yield as dependent value. From the slope of the line it is evident that the disease incidance had negetive effect on yield.The negative correlation between yield and PWI, might be due to the fact that higher population of bioagents resulted either in suppression of the pathogen population or exclusion of the pathogen from rhizosphere niches by their enhanced antagonists activity (Mulyaet al., 1996).

Earlier, Deuri (2013), reported positive compatibility amongst saprophytic antagonists like $P$. fluorescens, T.viride, M.anisopliae. Similar compatible observations amongst bioagents like $P$. fluorescens, T. viride, T.harzianum, M. anisopliae and Beauveria bassiana was made by Bora (2012) and Bora et al. (2013).

Dagostin et al. (2008) reported that Trichoderma $s p$. have ability to produce a series of antibiotics and fungal cell wall- 
degrading enzymes proteinase (Prb1), which play important role in mycoparasitism and mycelial lysis of the target pathogenic microbes. Durell (1968) documented with electron microphotography the haustoria and hyphae of $T$. viride within hyphae of Phycomycetes and digestion of their contents. Papavizas (1985) reported that $T$. harzianum could inhibit the growth of $R$. solanacearum by production of diffusible substances and overcrowding the pathogen. Bora et al. (2015) suggested utility of $T$. parareesei combined with other saprophytic antagonists for management of bacterial wilt of bhootjolokia caused by $R$. solanacearum . The present observation of antagonism of $T$. parareesei might be due to similar type of antagonistic mechanisms of parasitism.

Fluorescent pseudomonads could show diverse mechanisms of biocontrol which include antibiosis, cyanide production, siderophore production, competition for space and nutrient and induced systemic resistance. Root colonizing flourescent pseudomonads could suppress soil born pathogenic fungi by producing antifungal metabolites such as 2, 4diacetylphloroglucinol (DAPG), pyoluteorin (PLT), pyrrolnitrin (PRN), phenazines, and hydrogen cyanide (Haas and Defago 2005). Moreover, fluorescent pseudomonads produce yellow green fluorescent siderophores (pyoverdine type) under low iron condition, which is an important mechanism for the biocontrol activity of PGPR (Neilands and Leong, 1986; Bakker et al., 1993).

Fluorescent pseudomonads also activate ISR against various fungal, bacterial and viral diseases (Liu et al., 1995). The present observation of antagonism of $P$. fluorescens might be due to similar type of antibiosis, parasitism and ISR induced in tomato plant by $P$. fluorescens. Venkateswarlu et al. (2007) described that phosphate solubilizing bacteria (PSB) could solubilize the unavailable inorganic-P like tricalcium, iron, aluminium and rock phosphates into soluble forms by release of a variety of organic acids like succinic, citric, malic, fumaric, glyoxalic and gluconic acids. Besides plant growth promoting Bacillus sp. have been found to be very good antagonists against various fungal and bacterial pathogens. Lazzaretti et al. (1995) reported that $B$. subtilis could produce antagonistic proteins highly inhibitory to seed borne fungal and bacterial pathogens. Similarly, plant growth promotion, Azotobacter sp. could produce various antifungal compounds and suppress pathogenic or toxin producing soil microflora (Jen-Hshuan, 2006). Kamil et al. (2008) reported that, Azotobacter sp. could produce different growth hormones (IAA and other auxins, such as gibberllins and cytokinins), vitamins and siderophores. The present observation of antagonism of $B$. subtilis and A. chroococcum might be as a result of similar type of mechanisms or other growth enhancing mechanisms.

The decrease in disease incidence in tomato and increase in yield might be due to suppression of the pathogen by application of bioformulation of different bioactive microorganisms. This finding is in agreement with Bustamanate et al. (1989). Das (1999) recorded that $T$. viride and $T$. harzianum could significantly reduce the bacterial wilt severity caused by $R$. solanacearum in tomato. Similarly, Ranjan et al. (2002) reported that Trichoderma sp. could control rhizome rot of ginger caused by Pythium, Fusarium and $R$. solanacearum. Sutunya (1984) reported that $P$. fluorescens could effectively reduce the growth of $R$. solanacearum in rhizosphere of tomato plant. Similarly, Aspiras and Cruz (1985) observed the antagonistic activity of $P$. fluorescens against $R$. solanacearum in tomato and potato. 
Table.1 Compatibility amongst different bioactive microorganisms and their consortia

\begin{tabular}{|c|c|}
\hline Treatment combinations & $\begin{array}{l}\text { Compatible/ Non- } \\
\text { compatible }\end{array}$ \\
\hline Trichoderma parareesei (Control1) & $+\mathrm{ve}$ \\
\hline Pseudomonas fluorescens (Control2) & $+\mathrm{ve}$ \\
\hline Bacillus subtilis (Control3) & $+\mathrm{ve}$ \\
\hline Azotobacter chroococcum(Control4) & $+\mathrm{ve}$ \\
\hline T.parareesei $+P$. fluorescens & $+\mathrm{ve}$ \\
\hline T. parareesei+ B. subtilis & + ve \\
\hline T. parareesei+ A. chroococcum & + ve \\
\hline P. fluorescens + B. subtilis & $+\mathrm{ve}$ \\
\hline P. fluorescens + A. chroococcum & $+\mathrm{ve}$ \\
\hline B. subtilis + A. chroococcum & $+\mathrm{ve}$ \\
\hline$T$. parareesei+ P. fluorescens $+B$. subtilis & $+\mathrm{ve}$ \\
\hline T. parareesei+ P. fluorescens + A. chroococcum & $+\mathrm{ve}$ \\
\hline T. parareesei+ B. subtilis+ A. chroococcum & $+\mathrm{ve}$ \\
\hline P. fluorescens $+B$. subtilis + A. chroococcum & $+\mathrm{ve}$ \\
\hline T. parareesei+ P. fluorescens $+B$. subtilis + A. chroococcum & $+\mathrm{ve}$ \\
\hline
\end{tabular}

Table.2 Inhibition of $R$. solanacearum growth in vitro by different bioactive microorganisms and their consortia

\begin{tabular}{|c|c|c|}
\hline Treatment Combinations & $\begin{array}{l}\text { Radial growth Inhibited } \\
\text { (mm diam) }\end{array}$ & Inhibition $(\%)$ \\
\hline Control & 0.00 & $0.00(4.05) *$ \\
\hline Trichoderma parareesei & 48.55 & $53.94(26.64)$ \\
\hline Pseudomonas fluorescens & 45.00 & $50.00(30.00)$ \\
\hline Bacillus subtilis & 37.50 & $41.66(25.68)$ \\
\hline Azotobacterchroococcum & 25.00 & $27.77(16.13)$ \\
\hline T.parareesei + P. fluorescens & $43.00+31.50$ & $82.77(32.61)$ \\
\hline T.parareesei $+B$. subtilis & $44.00+19.50$ & $70.55(30.26)$ \\
\hline T.parareesei + A. chroococcum & $36.55+23.00$ & $66.16(27.33)$ \\
\hline P. fluorescens $+B$. subtilis & $38.33+24.67$ & $70.00(31.69)$ \\
\hline P. fluorescens + A. chroococcum & $34.66+17.50$ & $57.95(30.83)$ \\
\hline B. subtilis + A. chroococcum & $15.00+11.33$ & $29.25(25.89)$ \\
\hline T. parareesei $+P$. fluorescens $+B$. subtilis & $35.00+25.00+10.50$ & $78.33(39.07)$ \\
\hline T.parareesei $+P$. fluorescens + A. chroococcum & $38.50+26.33+8.11$ & $81.10(32.86)$ \\
\hline T. parareesei + B. subtilis + A. chroococcum & $36.00+16.00+7.33$ & $65.92(31.43)$ \\
\hline P. fluorescens $+B$. subtilis $+A$. chroococcum & $33.33+19.50+8.50$ & $68.14(36.66)$ \\
\hline $\begin{array}{l}\text { T. parareesei }+P . \text { fluorescens }+B . \text { subtilis }+A . \\
\text { chroococcum }\end{array}$ & $33.00+32.33+10.00+6.66$ & $91.10(49.43)$ \\
\hline S.Ed.$( \pm)$ & & 2.425 \\
\hline $\mathrm{CD}(0.05)$ & & 4.733 \\
\hline
\end{tabular}

*Data in the parentheses are angular transformed values 
Table.3 Effect of substrate based formulations of bioactive microorganisms on bacterial wilt incidence and yield of tomato

\begin{tabular}{|c|c|c|c|c|c|c|c|c|}
\hline \multirow[b]{2}{*}{ Treatments } & \multicolumn{2}{|c|}{$\begin{array}{c}\text { Disease incidence } \\
(\%)\end{array}$} & \multirow[b]{2}{*}{ Pooled } & \multirow{2}{*}{$\begin{array}{c}\text { Disease } \\
\text { reduction } \\
(\%)\end{array}$} & \multicolumn{2}{|c|}{$\begin{array}{c}\text { Yield } \\
(\mathrm{kg} / \text { plant })\end{array}$} & \multirow[b]{2}{*}{ Pooled } & \multirow{2}{*}{$\begin{array}{c}\text { Yield } \\
\text { increase } \\
\text { over } \\
\text { control } \\
(\%)\end{array}$} \\
\hline & 2013-14 & $\begin{array}{c}2014- \\
15\end{array}$ & & & $\begin{array}{c}2013- \\
14\end{array}$ & $\begin{array}{c}2014- \\
15\end{array}$ & & \\
\hline $\mathrm{T}_{1} *$ & $\begin{array}{c}4.42 \\
(12.13)^{* *}\end{array}$ & $\begin{array}{c}3.66 \\
(11.01)\end{array}$ & $\begin{array}{c}4.04 \\
(11.58)\end{array}$ & 95.09 & 1.644 & 1.741 & 1.692 & 358.54 \\
\hline $\mathrm{T}_{2}$ & $\begin{array}{c}10.72 \\
(19.10)\end{array}$ & $\begin{array}{c}9.82 \\
(18.26)\end{array}$ & $\begin{array}{c}10.27 \\
(18.68)\end{array}$ & 87.52 & 1.461 & 1.571 & 1.516 & 310.84 \\
\hline $\mathrm{T}_{3}$ & $\begin{array}{c}13.42 \\
(21.48)\end{array}$ & $\begin{array}{c}12.50 \\
(20.70)\end{array}$ & $\begin{array}{c}12.96 \\
(21.09)\end{array}$ & 84.25 & 1.378 & 1.518 & 1.448 & 292.41 \\
\hline $\mathrm{T}_{4}$ & $\begin{array}{c}15.46 \\
(23.15)\end{array}$ & $\begin{array}{c}14.56 \\
(22.43)\end{array}$ & $\begin{array}{c}15.01 \\
(22.79)\end{array}$ & 82.26 & 1.295 & 1.382 & 1.340 & 274.53 \\
\hline $\mathrm{T}_{5}$ & $\begin{array}{c}82.52 \\
(65.29)\end{array}$ & $\begin{array}{c}82.00 \\
(64.91)\end{array}$ & $\begin{array}{c}82.26 \\
(65.10)\end{array}$ & 81.75 & 0.359 & 0.379 & 0.369 & \\
\hline S.Ed. $( \pm)$ & 0.378 & 0.429 & 0.401 & & 0.058 & 0.055 & 0.055 & \\
\hline $\mathrm{CD}(0.05)$ & 0.652 & 0.739 & 0.689 & & 0.100 & 0.095 & 0.095 & \\
\hline
\end{tabular}

$* \mathrm{~T}_{1}=T$. parareesei $+P$. fluorescens $+B$. subtilis + A. chroococcum $; \mathrm{T}_{2}=T$. parareesei+ $P$. fluorescens $+B$. subtilis $;$ $\mathrm{T}_{3}=P$. fluorescens $+B$. subtilis + A. chroococcum; $\mathrm{T}_{4}=$ Biofor $-\mathrm{Pf}-2 ; \mathrm{T}_{5}=$ Control

* *Data in the parentheses are angular transformed values

Fig.1 Correlation between disease incidence and yield of tomato treated with different bioformulation consortia

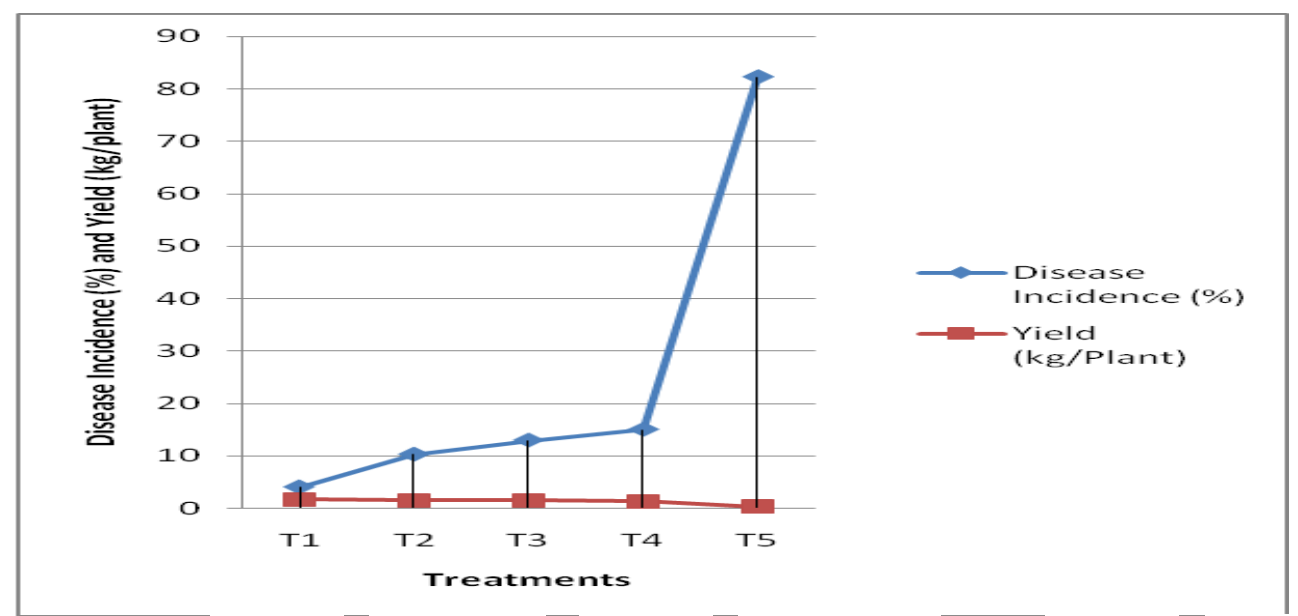

Where, $\mathrm{T}_{1}=T$. parareesei+ P. fluorescens $+B$. subtilis $+A$. chroococcum $; \mathrm{T}_{2}=T$. parareese $\bar{i}+P$. fluorescens + B. subtilis; $\mathrm{T}_{3}=$ P. fluorescens + B. subtilis + A. chroococcum $; \mathrm{T}_{4}=$ Biofor-Pf $-2 ; \mathrm{T}_{5}=$ Control

Das and Bora (2000) recorded biological control of bacterial wilt in tomato with $P$. fluorescens, B. subtilis, and Trichoderma sp. Rodriguez and Fraga (1999) observed simultaneous increases in $\mathrm{P}$ uptake and crop yields after inoculation with Bacillus firmus, $B$. polymyxa and B. cereus which indicated the advantage of the mixed inoculations of 
PGPR strains comprising PSB. Sutunya (1984) recorded slow disease development and reduced $R$. solanacearum when roots of tomato plants were inoculated with Bacillus cereus. Aspiras and Cruz (1985) observed reduced wilt incidence in tomato cultivar "Yellow plum" by treating the seedlings with B. polymyxa FU6 for 5 hr. Similarly, Karuna and Khan (1994) observed effectiveness of $B$. subtilis and B. polymyxa in inhibiting the growth of $R$. solanacearum under field condition.

Azotobacter is one of the potential contributor to plant growth with their ability to fix atmospheric nitrogen, promotes root hair formation in seedling roots, and increase plant weight during early crop growth stage (Rai and Gaur, 1988), produce phythormones and antibiotic substances and enhance mineral uptake etc. (Suneja and Lakshminarayana, 1998; Neumann and Romheld, 2001).

In addition to nitrogen fixation, siderophore production could be another property, contributing towards the agronomic utility of Azotobacter (Suneja and Lakshminarayana, 1998).

With the advent of green revolution in India during 1960s, the level of consumption of agro-chemicals has been held as yardstick of agricultural development. The green revolution boosted up agricultural production in India to an extent that largescale exports of many agricultural products become a reality. However, agro-chemicals also damaged the eco-system and the delicate balance between various components of interacting eco-system. So, a stage has now reached to review whether promoting the use of these toxic chemicals is appropriate strategy or not. One such new strategy, biological control of pathogens, although subject to numerous ecological limitations, is expected to become an important part of the control measures employed against many more diseases. In the present study, the application of $T$. parareese $i+P$. fluorescens $+B$. subtilis $+A$. chroococcum based bio-formulations promises as an effective biocontrol option along with better plant growth, yield and soil health management.

\section{Acknowledgements}

The authors are thankfully acknowledges the help and cooperation received from the DBT-AAU Centre, AAU, Jorhatand DBT, Govt. of India.

\section{References}

Annonymous (2013). Indian Horticulture Database, National Horticulture Board, Gurgaon, Haryana.

Aspiras, R.B. and Cruz, A.R. (1985). Potential biological control of bacterial wilt in tomato and potato with Bacillus polymyxa $\mathrm{Fu} 6$ and Pseudomonas fluorescens. In : Bacterial Wilt Disease in Asia and South pacific, pp. 89-92 (Eds.) Persley, G.D., ACIAR Procedings, No. 13, Sydney.

Bakker, P.A.H.M.; Raijmakers, M. and Scippers, B. (1993). Role of iron in the suppression of bacterial plant pathogens by flurescent Pseudomonads. In: Iron Chelation in Plant and Soil Micro-organisms. pp. 269-281. (Eds.) Barton, L. L. and Hemming, B.C., Academic Press, San Diego. USA.

Bora, L.C. (2012). Interactive effect between different bioagents. Programme on Biopesticides. Annual Report, DBTAAU Centre. 2012-13. pp. 35-40.

Bora, L.C.; Deuri, D. and Kataki, L. (2013). RAPD analysis of ginger germplasms 
of North East India and assessment of their resistance against bacterial wilt disease caused by Ralstonia solanacearum. Proc. World Biodiversity Cong., organized by Global Scientific Research Foundation, Chiang Mai Rajabhat University, Chiang Mai, Thailand, Nov. 26-30, 2013.

Bora, L.C.; Kataki L.; Talukdar K.; Nath, B.C. and Sarkar R. (2015).Molecular characterizations of microbial antagonists and development of bioformulations for management of bacterial wilt of Naga Chilli (Capsicum chinens Jacq.) in Assam. J.Exp.Biol.Agric.Sci.3 (2).

Bustamanate, G.P.; Ciampi-Panno, L. and Guaiquil, G. V. (1989). Inhibition in vitro of Pseudomonas solanacearum E.F. Smith using antagonistic strains of Pseudomonas fluorescens. Revista de. Microbiologia(Abstr.).

Dagostin, S.; Perazzolli, M.; Ferrarib, A.; Eladb, Y.and Pertota, I.(2008). Induction of systemic resistance against Plasmopara viticola in grapevine by Trichoderma harzianum T39 and benzothiadiazole. Biol. Control. 47(2): 228-234.

Das, B.K. (1999). Biomass production of Trichoderma harzianum Rifai and its formulation for management of stem rot of soyabean caused by Rhizoctonia solani Kuhn. M.Sc. (Agri.) Thesis, Assam agric. Univ., Jorhat, Assam, India.

Das, M. and Bora, L.C. (2000). Biological control of bacterial wilt of tomato caused by Ralstonia solanacearum. J. Agric. Sci. Soc. N. E. India 13(1): 5255.

Deuri, D. (2013) Bio-intensive approach for management of bacterial wilt of ginger (Zinziber officinale). M.Sc. (Agri) Thesis, Assam agric. Univ., Jorhat,
Assam, India.

Durell, L.W. (1968). Hyphal invasion by Trichoderma viride. Mycopath. Mycol. Appl.35: 138-144.

Jen-Hshuan Chen (2006). The combined use of chemical and organic fertilizers and/or biofertilizer for crop growth and soil fertility. International workshop on Sustained Management of the Soil-Rhizosphere System for Efficient Crop Production and Fertilizer Use. pp. 1-10.

Kamil, P.; Yami, K.D. and Singh, A. (2008). Plant Growth Promotional Effect of Azotobacter chroococcum, Piriformospora indica and vermicompost on rice plant. Nepal J. Sci. Tech. 9: 85-90.

Kumar, P. and Sood, A.K. (2001). Integration of antagonistic rhizobacteria and soil solarisation for the management of bacterial wilt of tomato caused by Ralstonia solanacearum. Indian Phytopath. 54(1): 12-15.

Liu, L.; Kloepper, J.W. and Tuzum, S. (1995). Induction of systemic resistance against cucumber mosaic virus by seed inoculation with selected rhizobacterial strains. Phytopathology, 82: 1108-1109.

Mulya, K.; Watanable, M.; Goto, M.; Takikawa, Y. and Tsuyumu, S. (1996). Suppression of bacterial wilt disease of tomato by root dipping with Pseudomonas fluorescens Pf G32- the role of antibiotic substances and siderophore production. Ann. Phytopath. Soc. Japan62: 134-140.

Neilands, J.B. and Leong, S.A. (1986). Siderophore in relation to plant growth and disease. Annu. Rev. Plant Pathol. 37: 187-208.

Neumann, G. and Romheld, V. (2001). The release of root exudates as affected by plant's physiological status. In: The 
rhizosphere. Biochemistry and organic substances at the soil- plant interface. pp. 41-93. Pinton R., Varini, Z. and Marcel Dekker (Eds.), CRC Press, New York.

Papavizas, G.C. (1985). Trichoderma and Gliocladium: Biology, ecology and potential for biocontrol. Annu. Rev. Phytopathol. 23: 23-54.

Rai, S.N. and Gaur, A.C. (1988). Characterization of Azotobacterspp and effect of Azotobacter and Azospirillum as inoculants on the yield and N-uptake of wheat crop. Plant Soil. 109: 131-134.

Ranjan, R.P.; Gupta, S.R.; Sarma, Y.R. and Jackson, G.V.H. (2002). Diseases of ginger and their control with Trichoderma harzianum. Indian Phytopath.55 (2): 173-177.

Rodriguez, H. and Fraga, R. (1999). Phosphate solubilizing bacteria and their role in plant growth promotion. Biotechnol. Adv. 17: 319-339.

Srivastava R.; Khalid, A.; Singh, U.S. and Sharma, A.K. (2010). Evaluation of arbuscular mycorrhizal fungus, fluorescent Pseudomonas and Trichoderma harzianum formulation against Fusarium oxysporumf.sp. lycopersici for the management of tomato wilt. Biol. Control 53(1): 2431.

Suneja, S. and Lakshminarayana, K. (1998). Inhibition of phytopathogens by certain strains of Azotobacter chroococcum under in vitro conditions. Indian Phytopath.51 (2): $140-145$.

Sutunya, C. (1984). Studies on Bacterial Wilt of Tomato. Bangkok (Thailand). pp. 104.

Venkateswarlu, B.; Balloli, S.S. and Ramakrishna, Y.S. (2007).Organic farming in rainfed Agriculture. Central research institute for dry land agriculture, Hyderabad.p. 88.

Weller, D.M. and Cook, R.S. (1983). Suppression of take-all of wheat by seed treatments with fluorescent pseudomonads. Phytopathol.73: 463469.

\section{How to cite this article:}

Bharat C. Nath, L.C. Bora, L. Kataki, K. Talukdar, P. Sharma, J. Dutta and Khan, P. 2016. Plant Growth Promoting Microbes, their Compatibility Analysis and Utility in Biointensive Management of Bacterial Wilt of Tomato. Int.J.Curr.Microbiol.App.Sci. 5(6): 1007-1016. doi: http://dx.doi.org/10.20546/ijcmas.2016.506.107 